Potravinarstvo Slovak Journal of Food Sciences

vol. 14, 2020, p. 929-936

https://doi.org/10.5219/1431

Received: 1 July 2020. Accepted: 12 August 2020.

Available online: 28 October 2020 at www.potravinarstvo.com

(C) 2020 Potravinarstvo Slovak Journal of Food Sciences, License: CC BY 3.0

ISSN 1337-0960 (online)

\title{
THE EFFECT OF STORAGE ON THE QUALITY PARAMETERS OF BABY FOOD
}

\author{
Hyrije Koraqi, Namik Durmishi, Diellëza Azemi, Sara Selimi
}

\begin{abstract}
The aim of this paper was focused on the quality changes of baby food stored at different temperature $\left(4{ }^{\circ} \mathrm{C}, 20^{\circ} \mathrm{C}, 40{ }^{\circ} \mathrm{C}\right.$ and $60{ }^{\circ} \mathrm{C}$ ) for 15 days. During storage, chemical and nutritional parameters analysis were carried out. Commercial fruits based baby food are the products usually made with fruits, sugar, and variable additives. As the foodstuffs intended for particular nutritional uses, baby foods for infants and young children conform to a set of strict guidelines e.g. nutritional quality, the addition of additives, labeling. However, being an important supplement to children's diet and for their progressive adaptation to ordinary food, the nutritional quality of commercial fruits baby food is very important. Samples of commercial fruits baby food from the market and pharmacies were analyzed by parameters: $\mathrm{pH}$, total soluble solids, moisture, total acidity, vitamin C, proteins, sugars, and lipids. All samples of baby food are produced by foreign companies since currently, no Kosovo manufacturers are producing this range of products. The nutritional quality parameters are important to assess the quality of the product and how it can be safely stored. However, as a precaution, storage remarks in the product labels should always be followed.
\end{abstract}

Keywords: baby food; nutritional content; chemical composition; fruits

\section{INTRODUCTION}

Commercial fruits based baby food are the products usually made with fruits, sugar, water, and variable additives. Nutrient-rich baby foods are required with particularly high standards of quality and safety expressed through product specifications or attributes. As the foodstuffs intended for particular nutritional uses, baby foods for infants and young children conform to a set of strict guidelines e.g. nutritional quality, the addition of additives, labeling (Čižková et al., 2009; Calabretti et al., 2017; Azemi et al., 2019). Commercial fruits baby food is suitable for use during the complementary feeding period. These foods are specifically formulated with appropriate nutritional quality to provide additional energy and nutrients to complement the family foods derived from the local diet by providing those nutrients which are either lacking or are present in insufficient quantities (Codex Alimentarius, 1991). However, being an important supplement to children's diet and for their progressive adaptation to ordinary food, the nutritional quality of commercial fruits baby food is very important. Fruitsvegetable based foods are easy to digest and offer high nutrient density. The nutrition value of baby food deeply depends on the composition, what raw materials are used and what are the proportions of fruit or vegetable content (Zein, ElSayed Bhnsawy and Arafa, 2019; Seidel et al., 2015). There is much evidence that the quality and composition of commercial baby food may contribute to the present and future health benefits of young children.
Since infants between 6 months and 3 years of age are rather limited in their food choices, the commercial baby foods serve as an important source of energy, basic nutrients, fiber, vitamins, and minerals and establish their taste and eating patterns (Č́ž́̌ková et al., 2009).

Infant fruits play an important role in the complementary feeding period. Infant fruits are defined as "processed fruit-based foods" that are divided into "simple fruits which are or have to be reconstituted with milk or other appropriate nutritious liquids". Nutrition and dietary habits during infancy and early childhood play a role in shaping eating habits and health later in adolescence and into adulthood (Walker and Goran, 2015; Prchalová et al., 2016). In many countries, infant fruits are among the first foods that are introduced at the beginning of the complementary feeding period. In recent decades, the reduction of time to be dedicated to the preparation of home meals has already led to the appearance of ready-toeat food products on the market. The foods specifically manufactured for infants and young children have had an evolution. Prepared baby foods and formulas, intended for use of children aged between 4 months and 3 years, provide an appealing alternative for working mothers (García et al., 2015; Garcia et al., 2014).

The aim of this paper was focused on the quality changes of baby food stored at different temperature $\left(4^{\circ} \mathrm{C}, 20^{\circ} \mathrm{C}\right.$, $40^{\circ} \mathrm{C}$, and $60^{\circ} \mathrm{C}$ ) for 15 days.

The imbalance of calories and nutrients in some of the baby foods necessitates encouraging breast feeding at least 
during the first 6 months. The high protein contents may damage the kidney and the quantity and quality of protein in baby foods should be adjusted to simulate human milk. The protein quality may be improved by improving the processing and storage conditions. To reduce the risk of dental caries, baby foods in which sucrose should be replaced by glucose or lactose may be selected (AlOthman, Khan and Al-Kanhal, 1997; Kohlboeck et al., 2012; Jackson, 2015). Nutrition education of mothers and health workers in kindergarten on the selection and preparation of the right type of baby foods and weaning practices will go a long way in improving the nutritional status of infants and children in the country.

Samples of commercial fruits based baby food from the market and pharmacies were analyzed by parameters: $\mathrm{pH}$, total soluble solids, dry matter, total acidity, vitamin C, sugars (total sugars, reducing sugars), proteins, and lipids. All samples of baby food are produced by foreign companies since currently, no Kosovo manufacturers are producing this range of products. This is the first research of this type in Kosovo and it should give us a novel result. The nutritional quality parameters are important to assess the quality of the product and how it can be safely stored. However, as a precaution, storage remarks in the product labels should always be followed.

\section{Scientific hypothesis}

The scientific hypothesis of this study was focused on the quality changes of baby food stored at different temperature $\left(4{ }^{\circ} \mathrm{C}, 20^{\circ} \mathrm{C}, 40{ }^{\circ} \mathrm{C}\right.$, and $\left.60^{\circ} \mathrm{C}\right)$ for 15 days. During storage, chemical and nutritional parameters analysis were carried out. Quality parameters content was estimated at the beginning of the experiment and subsequently at 15 days interval.

\section{MATERIAL AND METHODOLOGY}

\section{Sampling Preparation}

Samples of commercial fruits based baby food with trade name: HiPP (Apple and Berry fruits), HiPP (Plum), HiPP (Apple and Banana), HiPP (Pear), FRUTEK (Banana), and HELLO (Carrot and Apple) were purchased from the market and pharmacies in Kosovo during the period June 2019. After samples collection, they were stored at different temperatures $\left(4{ }^{\circ} \mathrm{C}, 20^{\circ} \mathrm{C}, 40{ }^{\circ} \mathrm{C}\right.$, and $\left.60{ }^{\circ} \mathrm{C}\right)$ for 15 days.

$0.5 \mathrm{~g}$ of the product was diluted in $10 \mathrm{~mL}$ of acidified distilled water $(1 \%)$ and extracted for 10 minutes. The solution was centrifuged at $3000 \mathrm{rpm}$ for 10 minutes. The solid fraction, separated from the supernatant, was then subjected to a new extraction step. The liquid phases were collected and brought to a final volume of $10 \mathrm{~mL}$. All analyses were performed in triplicate.

\section{Nutritional analysis}

Nutrient analysis was done for all collected samples. Determination of nutritional properties of commercial fruits baby food with trade name: HiPP (Apple and Berry fruits), HiPP (Plum), HiPP (Apple and Banana), HiPP (Pear), FRUTEK (Banana), and HELLO (Carrot and Apple) were performed according to the standard methods of the AOAC (2005) and AOAC (2016). Total soluble solids content (TSS) measured using the Abbe refractometer calibrate against sucrose and expressed in ${ }^{\circ}$ Brix. Titratable acidity (TA) was measured according to AOAC Method (AOAC, 2005; AOAC, 2016) and expressed as milligrams of citric acid. $\mathrm{pH}$ was measured using $\mathrm{pH} / \mathrm{mv}$ meter, and dry matter (DM) was measured in triplicate by drying $5 \mathrm{~g}$ of the fresh fruits at $105{ }^{\circ} \mathrm{C}$ until constant weight ( $4-6$ hours). The determination of lipids was done by Soxhlet extraction after digestion of the samples by hydrochloric acid hydrolysis, followed by extraction of the fats with petroleum ether. After the extraction, lipid content was determined by weighing (AOAC, 2005). Protein was determined by the Bradford method with some modifications. Gelatin is commonly used to create the standard curve, and the absorption is measured at $545 \mathrm{~nm}$ in a spectrophotometer. Reducing sugar was determined using the method of Lane and Eynon and Fehling's solution as described by AOAC Methods (AOAC, 2005; AOAC, 2016). Total sugars were determined by the phenol sulfuric acid method (Nielsen, 2009). Glucose is commonly used to create the standard curve, and the absorption is measured at $490 \mathrm{~nm}$. Vitamin C content was estimated using a spectrophotometric method with 2,4-dinitrophenyl hydrazine as an indicator (AOAC, 2005; AOAC, 2016). Samples were homogenized with metaphosphoric acid (5\% metaphosphoric acid in $10 \%$ acetic acid solution in water), filtered and treated with $85 \%$ sulphuric acid solution and 2,4-dinitrophenyl hydrazine, and then incubated at $60{ }^{\circ} \mathrm{C}$ for $60 \mathrm{~min}$ in a water bath. Absorbance was measured at $520 \mathrm{~nm}$ in a spectrophotometer (Genesys 10S UV-Visible) for the estimation of vitamin $\mathrm{C}$ in the fruits.

\section{Statistical analysis}

All data were expressed as the mean \pm standard deviation of triplicate experiments. All statistical analyses performed using the MS Excel program and SPSS 22.0 statistics software Differences were tested for significance using the ANOVA procedure, with a significance level of $p<0.05$.

\section{RESULTS AND DISCUSSION}

Samples of commercial fruits based baby food with trade name: HiPP (Apple and Berry fruits), HiPP (Plum), HiPP (Apple and Banana), HiPP (Pear), FRUTEK (Banana), and HELLO (Carrot and Apple) were purchased from the market and pharmacies in Kosovo during the period June 2019. The effect of storage on quality changes of baby food is given in Table 1, Table 2, and Figure 1.

The $\mathrm{pH}$ values of commercial fruits-based baby food were decreased during storage (Table 1). The average $\mathrm{pH}$ value ranging from $3.55 \pm 0.1$ to $2.85 \pm 0.1$ sample A2 HiPP (Plum), $3.88 \pm 0.1$ to $3.68 \pm 0.1$ to sample A4 HiPP (Pear), $3.93 \pm 0.1$ to $3.69 \pm 0.1$ sample A6 HELLO (Carrot and Apple), $3.94 \pm 0.1$ to $2.94 \pm 0.1$ sample A1 HiPP (Apple and Berry fruits), $3.98 \pm 0.1$ to $3.55 \pm 0.1$ sample A3 HiPP (Apple and banana) and highest $4.31 \pm 0.1$ to $4.15 \pm 0.1$ sample A5 FRUTEK (Banana). Statistical analysis showed that storage interval and temperature treatments had a significant $(p<0.05)$ effect on the $\mathrm{pH}$ value of all samples. 
Table 1 The chemical composition of commercial fruits based baby food.

\begin{tabular}{|c|c|c|c|c|c|c|c|}
\hline Sample & $\begin{array}{c}\text { Temperature } \\
{\left[{ }^{\circ} \mathrm{C}\right]}\end{array}$ & $\begin{array}{c}\text { Time of } \\
\text { Storage } \\
\text { [Days] }\end{array}$ & pH & $\overline{W(D M) / \%}$ & TSS $/^{\circ}$ Brix & TA/\% & $\begin{array}{l}\text { Vitamin C } \\
{\text { mg. } 100 \mathrm{~g}^{-1}}\end{array}$ \\
\hline $\begin{array}{l}A_{1} \\
\text { HiPP(Apple/ } \\
\text { Berry fruits) }\end{array}$ & $\begin{array}{l}4{ }^{\circ} \mathrm{C} \\
20{ }^{\circ} \mathrm{C} \\
40{ }^{\circ} \mathrm{C} \\
60^{\circ} \mathrm{C}\end{array}$ & 15 & $\begin{array}{l}3.94 \pm 0.1 \\
3.92 \pm 0.1 \\
3.54 \pm 0.1 \\
2.94 \pm 0.1\end{array}$ & $\begin{array}{l}1.34 \pm 0.1 \\
1.34 \pm 0.1 \\
1.29 \pm 0.1 \\
1.08 \pm 0.1\end{array}$ & $\begin{array}{l}7.0 \pm 0.1 \\
7.0 \pm 0.1 \\
7.6 \pm 0.1 \\
8.2 \pm 0.1\end{array}$ & $\begin{array}{l}0.61 \pm 0.2 \\
0.60 \pm 0.2 \\
0.52 \pm 0.2 \\
0.41 \pm 0.2\end{array}$ & $\begin{array}{l}30 \pm 0.2 \\
30 \pm 0.2 \\
25 \pm 0.2 \\
20 \pm 0.2\end{array}$ \\
\hline $\begin{array}{l}A_{2} \\
\text { HiPP (Plum) }\end{array}$ & $\begin{array}{l}4{ }^{\circ} \mathrm{C} \\
20^{\circ} \mathrm{C} \\
40^{\circ} \mathrm{C} \\
60^{\circ} \mathrm{C}\end{array}$ & 15 & $\begin{array}{l}3.55 \pm 0.1 \\
3.53 \pm 0.1 \\
3.10 \pm 0.1 \\
2.85 \pm 0.1\end{array}$ & $\begin{array}{l}3.35 \pm 0.1 \\
3.35 \pm 0.1 \\
3.20 \pm 0.1 \\
3.00 \pm 0.1\end{array}$ & $\begin{array}{l}6.2 \pm 0.1 \\
6.2 \pm 0.1 \\
6.8 \pm 0.1 \\
7.5 \pm 0.1\end{array}$ & $\begin{array}{l}0.55 \pm 0.2 \\
0.55 \pm 0.2 \\
0.49 \pm 0.2 \\
0.40 \pm 0.2\end{array}$ & $\begin{array}{l}30 \pm 0.2 \\
30 \pm 0.2 \\
25 \pm 0.2 \\
20 \pm 0.2\end{array}$ \\
\hline $\begin{array}{l}\text { A3 } \\
\text { HiPP(Apple/ } \\
\text { Banana) }\end{array}$ & $\begin{array}{l}4{ }^{\circ} \mathrm{C} \\
20{ }^{\circ} \mathrm{C} \\
40{ }^{\circ} \mathrm{C} \\
60{ }^{\circ} \mathrm{C}\end{array}$ & 15 & $\begin{array}{l}3.98 \pm 0.1 \\
3.98 \pm 0.1 \\
3.85 \pm 0.1 \\
3.55 \pm 0.1\end{array}$ & $\begin{array}{l}2.24 \pm 0.1 \\
2.24 \pm 0.1 \\
2.15 \pm 0.1 \\
2.04 \pm 0.1\end{array}$ & $\begin{array}{l}5.0 \pm 0.1 \\
5.0 \pm 0.1 \\
5.6 \pm 0.1 \\
6.2 .0 \pm 0.1\end{array}$ & $\begin{array}{l}0.58 \pm 0.2 \\
0.56 \pm 0.2 \\
0.45 \pm 0.2 \\
0.38 \pm 0.2\end{array}$ & $\begin{array}{l}8.9 \pm 0.2 \\
8.9 \pm 0.2 \\
8.1 \pm 0.2 \\
7.2 \pm 0.2\end{array}$ \\
\hline $\begin{array}{l}\text { A4 } \\
\text { HiPP (Pear) }\end{array}$ & $\begin{array}{l}4{ }^{\circ} \mathrm{C} \\
20{ }^{\circ} \mathrm{C} \\
40{ }^{\circ} \mathrm{C} \\
60{ }^{\circ} \mathrm{C}\end{array}$ & 15 & $\begin{array}{l}3.88 \pm 0.1 \\
3.88 \pm 0.1 \\
3.79 \pm 0.1 \\
3.68 \pm 0.1\end{array}$ & $\begin{array}{l}2.43 \pm 0.1 \\
2.43 \pm 0.1 \\
2.33 \pm 0.1 \\
2.23 \pm 0.1\end{array}$ & $\begin{array}{l}4.75 \pm 0.1 \\
4.75 \pm 0.1 \\
5.30 \pm 0.1 \\
5.90 \pm 0.1\end{array}$ & $\begin{array}{l}0.48 \pm 0.2 \\
0.46 \pm 0.2 \\
0.39 \pm 0.2 \\
0.28 \pm 0.2\end{array}$ & $\begin{array}{l}10 \pm 0.2 \\
10 \pm 0.2 \\
5.4 \pm 0.2 \\
1.6 \pm 0.2\end{array}$ \\
\hline $\begin{array}{l}\text { A5 } \\
\text { FRUTEK(Banana) }\end{array}$ & $\begin{array}{l}4{ }^{\circ} \mathrm{C} \\
20{ }^{\circ} \mathrm{C} \\
40{ }^{\circ} \mathrm{C} \\
60{ }^{\circ} \mathrm{C}\end{array}$ & 15 & $\begin{array}{l}4.31 \pm 0.1 \\
4.31 \pm 0.1 \\
4.25 \pm 0.1 \\
4.15 \pm 0.1\end{array}$ & $\begin{array}{l}2.61 \pm 0.1 \\
2.61 \pm 0.1 \\
2.52 \pm 0.1 \\
2.43 \pm 0.1\end{array}$ & $\begin{array}{l}5.1 \pm 0.1 \\
5.1 \pm 0.1 \\
5.7 \pm 0.1 \\
6.4 \pm 0.1\end{array}$ & $\begin{array}{l}0.35 \pm 0.2 \\
0.35 \pm 0.2 \\
0.28 \pm 0.2 \\
0.21 \pm 0.2\end{array}$ & $\begin{array}{l}8.7 \pm 0.2 \\
8.7 \pm 0.2 \\
7.6 \pm 0.2 \\
6.3 \pm 0.2\end{array}$ \\
\hline $\begin{array}{l}\text { A6 } \\
\text { HELLO(Carrot/ } \\
\text { Apple) }\end{array}$ & $\begin{array}{l}4{ }^{\circ} \mathrm{C} \\
20{ }^{\circ} \mathrm{C} \\
40{ }^{\circ} \mathrm{C} \\
60^{\circ} \mathrm{C}\end{array}$ & 15 & $\begin{array}{l}3.93 \pm 0.1 \\
3.93 \pm 0.1 \\
3.81 \pm 0.1 \\
3.69 \pm 0.1\end{array}$ & $\begin{array}{l}2.13 \pm 0.1 \\
2.13 \pm 0.1 \\
2.05 \pm 0.1 \\
1.94 \pm 0.1\end{array}$ & $\begin{array}{l}6.1 \pm 0.1 \\
6.1 \pm 0.1 \\
6.8 \pm 0.1 \\
7.7 \pm 0.1\end{array}$ & $\begin{array}{l}0.30 \pm 0.2 \\
0.30 \pm 0.2 \\
0.23 \pm 0.2 \\
0.15 \pm 0.2\end{array}$ & $\begin{array}{l}10 \pm 0.2 \\
10 \pm 0.2 \\
5.4 \pm 0.2 \\
4.5 \pm 0.2\end{array}$ \\
\hline
\end{tabular}

\footnotetext{
Note: Data are expressed as average value \pm standard deviation of three replicates.
} 


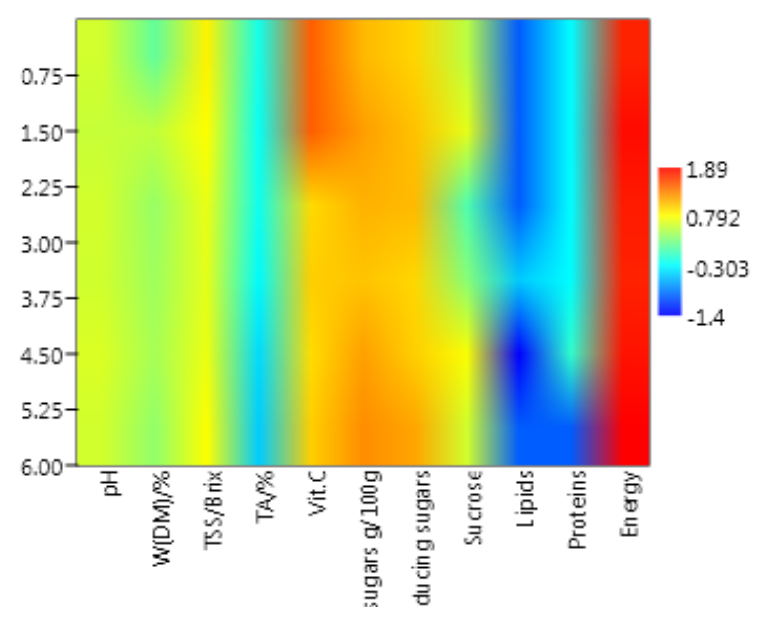

Figure 1 The $3 \mathrm{D}$ visualization data of chemical and nutritional parameters of baby food.

Our results correspond with the results of the work Carbonell-Capella et al. (2014), Zulueta et al. (2007) reported that the $\mathrm{pH}$ values of commercial fruits-based baby foods in the range of $3.54-4.12$ and $\mathrm{pH}$ range $2.96-4.11$ respectively. Similar results reached Usal and Sahan (2020), who report that the $\mathrm{pH}$ of the commercial baby food ranged from $3.55-5.24$. Touati et al. (2016) reported that the $\mathrm{pH}$ values were significantly decreased during this period, independently of the temperature used. Prior storage, $\mathrm{pH}$ values were $3.88,3.57$, and 2.77. The $\mathrm{pH}$ of fruits is lower than vegetables and therefore vitamin $\mathrm{C}$ is less degraded in fruits (Mesías-García, GuerraHernández, and García-Villanova, 2010).

The values for commercial fruits-based baby food of the total dry matter were decreased during storage (Table 1). The average value ranged from $1.34 \pm 0.1$ to $1.08 \pm 0.1$ sample A1 HiPP (Apple and Berry fruits) and increasing on other samples: $2.13 \pm 0.1$ to $1.94 \pm 0.1$ sample A6 HELLO (Carrot and Apple), $2.24 \pm 0.1$ to $2.04 \pm 0.1$ sample A3 HiPP (Apple and banana), $2.43 \pm 0.1$ to $2.23 \pm 0.1$ sample A4 HiPP (Pear), $2.61 \pm 0.1$ to $2.43 \pm 0.1$ sample A5 FRUTEK (Banana) and to be higher value is $3.35 \pm 0.1$ to $3.35 \pm 0.1$ sample A2 HiPP (Plum). Statistical analysis showed that storage interval and temperature treatments had a significant $(p<0.05)$ effect on the total dry matter value of all samples.

Usal and Sahan (2020), reported that the dry matter levels of samples were varied between 81.41 and $93.10 \%$ depending on ingredients. When the dry matter of the samples was examined, the highest value was found in $14(93.10 \%)$ sample and the lowest value in $11(81.41 \%)$. These values are much higher than our results.

An increase was observed in soluble solids $\mathrm{TSS} /{ }^{\circ}$ Brix of samples of commercial fruits baby food throughout the storage (Table 1). The average value ranged from $4.75 \pm 0.1$ to $5.90 \pm 0.1$ sample A4 HiPP (Pear), and increasing on other samples: $5.0 \pm 0.1$ to $6.2 \pm 0.1$ sample A3 HiPP (Apple and banana), $5.1 \pm 0.1$ to $6.4 \pm 0.1$ sample A5 FRUTEK (Banana), $6.1 \pm 0.1$ to $7.7 \pm 0.1$ sample A6 HELLO (Carrot and apple), $6.2 \pm 0.1$ to $7.5 \pm 0.1$ sample A2 HiPP (Plum) and highest $7.0 \pm 0.1$ to $8.2 \pm 0.1$ sample A1 HiPP (Apple and Berry fruits). The increase in soluble solids $\mathrm{TSS} /{ }^{\circ} \mathrm{Brix}$ value may be due to an increase in temperature and inversion of sucrose into glucose and fructose. Statistically, storage interval and treatments had significantly $(p<0.05)$ effect on soluble solids $\mathrm{TSS} /{ }^{\circ} \mathrm{Brix}$ value of all samples during storage.

Different authors have observed that the TSS $/{ }^{\circ}$ Brix value increased during storage at different temperatures. Zulueta et al. (2007) reported that the $\mathrm{TSS} /{ }^{\circ} \mathrm{Brix}$ ranged from 14.0 to 24.9. Touati et al. (2016) reported a significant increase in $\mathrm{TSS} /{ }^{\circ}$ Brix was observed for all the samples during storage $11.60-15.20$. Carbonell-Capella et al. (2014) reported that the $\mathrm{TSS} /{ }^{\circ}$ Brix ranged from 12.0 to 24.9. Our results were the lowest of these studies.

The total acidity in samples of commercial fruits baby food was decreased during the storage period (Table 1). The average value for total acidity is lower ranged from expressed in $\%$ of citric acid and ranged from $0.30 \pm 0.2$ to $0.15 \pm 0.2$ sample A6 HELLO (Carrot and Apple) while the highest values of total acidity are in the sample A1 HiPP (Apple and Berry fruits) $0.61 \pm 0.2$ to $0.41 \pm 0.2$. The reason behind the increase in acidity is the degradation of non-reducing sugar which increases the acidity. Total acidity was statistically significantly $(p<0.05)$ affected by storage intervals and temperature treatments.

Organic acids in fruits exhibit a low susceptibility to changes during processing and storage, combined with adequate stability compared to pigments and flavor compounds (Fügel, Carle and Schieber, 2005). Many authors have been observed that fruit-based products showed acidic properties in studies conducted. The total acidity showed a decrease during storage in their studies (Zulueta et al., 2007; Jie et al., 2013; Batkan, Kundakçi, and Ergönül, 2012). Our findings are similar to those found by them. Our results correspond with the results of the studies Usal and Sahan (2020) reported that the total titratable acidity ( $\mathrm{g}$ of citric acid mg. $100 \mathrm{~g}^{-1}$ ) was between 0.15 and $0.54 \mathrm{mg} 100 \mathrm{~g}^{-1}$. Similar results observed Carbonell-Capella et al. (2014), who report that the total acidity ( $\mathrm{g}$ of citric acid per $100 \mathrm{~g}$ ) of the commercial baby food was between 0.308 and $0.533 \mathrm{~g}$ of citric acid per $100 \mathrm{~g}$. 
Table 2 The nutritional composition of commercial fruits based baby food.

\begin{tabular}{|c|c|c|c|c|c|c|}
\hline Sample & $\begin{array}{l}\text { Temperature } \\
{\left[{ }^{\circ} \mathrm{C}\right]}\end{array}$ & $\begin{array}{l}\text { Time of } \\
\text { Storage } \\
\text { [Days] }\end{array}$ & $\begin{array}{l}\text { Total } \\
\text { sugars } \\
\text { g.100g }\end{array}$ & $\begin{array}{l}\text { Reducing } \\
\text { sugars } \\
\text { g.100g }\end{array}$ & $\begin{array}{l}\text { Lipids } \\
\text { g.100g }\end{array}$ & $\begin{array}{l}\text { Proteins } \\
\text { g.100 } \mathrm{g}^{-1}\end{array}$ \\
\hline$\overline{\mathbf{A}_{1}}$ & $4^{\circ} \mathrm{C}$ & \multirow{4}{*}{15} & $12.4 \pm 0.1$ & $9.2 \pm 0.1$ & $0.1 \pm 0.1$ & $0.5 \pm 0.1$ \\
\hline HiPP(Apple/ & $20^{\circ} \mathrm{C}$ & & $12.4 \pm 0.1$ & $9.2 \pm 0.1$ & $0.1 \pm 0.1$ & $0.5 \pm 0.1$ \\
\hline \multirow[t]{2}{*}{ Berry fruits) } & $40{ }^{\circ} \mathrm{C}$ & & $11.4 \pm 0.1$ & $10.2 \pm 0.1$ & $0.1 \pm 0.1$ & $0.5 \pm 0.1$ \\
\hline & $60^{\circ} \mathrm{C}$ & & $10.2 \pm 0.1$ & $11.3 \pm 0.1$ & $0.1 \pm 0.1$ & $0.5 \pm 0.1$ \\
\hline
\end{tabular}

$\mathbf{A}_{2}$ HiPP (Plum)

$4{ }^{\circ} \mathrm{C}$

$20^{\circ} \mathrm{C}$

$40{ }^{\circ} \mathrm{C}$

$60{ }^{\circ} \mathrm{C}$

$\mathbf{A}_{3}$

HiPP(Apple/

Banana)

$\mathrm{A}_{4}$

HiPP (Pear)

$4{ }^{\circ} \mathrm{C}$

$20^{\circ} \mathrm{C}$

$40{ }^{\circ} \mathrm{C}$

$60{ }^{\circ} \mathrm{C}$

$20^{\circ} \mathrm{C}$

$40^{\circ} \mathrm{C}$

$60{ }^{\circ} \mathrm{C}$
15

$16.0 \pm 0$.

$16.0 \pm 0.1$

$15.1 \pm 0.1$

$13.9 \pm 0.1$

$11.2 \pm 0.1$

$12.3 \pm 0.1$

$13.4 \pm 0.1$

15

$4{ }^{\circ} \mathrm{C}$

$20^{\circ} \mathrm{C}$

$40{ }^{\circ} \mathrm{C}$

$60{ }^{\circ} \mathrm{C}$
15

15

15
$13.2 \pm 0.1$

$13.2 \pm 0.1$

$12.2 \pm 0.1$

$11.1 \pm 0.1$

$12.1 \pm 0.1$

$12.1 \pm 0.1$

$13.2 \pm 0.1$

$14.3 \pm 0.1$

$0.1 \pm 0.1$

$0.1 \pm 0.1$

$0.1 \pm 0.1$

$0.1 \pm 0.1$

$0.5 \pm 0.1$

$0.5 \pm 0.1$

$0.5 \pm 0.1$

$0.5 \pm 0.1$

$\begin{array}{ll}\text { FrUTEK(Banana) } & 20{ }^{\circ} \mathrm{C} \\ & 40{ }^{\circ} \mathrm{C} \\ & 60{ }^{\circ} \mathrm{C}\end{array}$

\section{$11.0 \pm 0.1$ \\ $11.0 \pm 0.1$ \\ $10.1 \pm 0.1$}

$9.0 \pm 0.1$

$9.10 \pm 0.1$

$9.10 \pm 0.1$

$10.2 \pm 0.1$

$11.3 \pm 0.1$

$0.3 \pm 0.01$

$0.3 \pm 0.01$

$0.3 \pm 0.01$

$0.3 \pm 0.01$

$0.5 \pm 0.1$

$0.5 \pm 0.1$

$0.5 \pm 0.1$

$0.5 \pm 0.1$

\begin{tabular}{|c|c|c|c|c|c|c|}
\hline A6 & $4{ }^{\circ} \mathrm{C}$ & 15 & $18.9 \pm 0.1$ & $15.0 \pm 0.1$ & $0.1 \pm 0.1$ & $0.1 \pm 0.1$ \\
\hline HELLO(Carrot/ & $20^{\circ} \mathrm{C}$ & & $18.9 \pm 0.1$ & $15.0 \pm 0.1$ & $0.1 \pm 0.1$ & $0.1 \pm 0.1$ \\
\hline Apple) & $40^{\circ} \mathrm{C}$ & & $17.5 \pm 0.1$ & $16.1 \pm 0.1$ & $0.1 \pm 0.1$ & $0.1 \pm 0.1$ \\
\hline & $60^{\circ} \mathrm{C}$ & & $16.3 \pm 0.1$ & $17.2 \pm 0.1$ & $0.1 \pm 0.1$ & $0.1 \pm 0$ \\
\hline
\end{tabular}

Note: Data are expressed as average value \pm standard deviation of three replicates. 
Samples of commercial fruits baby food are a good source of Vitamin C. Some sample is fortified with Vitamin $\mathrm{C}$ and contains high value of Vitamin C. The stability of Vitamin $\mathrm{C}$ decreases with increasing temperature. A decrease in Vitamin $\mathrm{C}$ in samples of commercial fruits baby food during storage (Table 1). The highest average value of Vitamin C is A1 HiPP (Apple and Berry fruits) $30 \pm 0.2$ to $20 \pm 0.2$ also and sample A2 HiPP (Plum) $30 \pm 0.2$ to $20 \pm 0.2$. The relatively high amounts of Vitamin $\mathrm{C}$ also contain the samples: A4 HiPP (Pear) $10 \pm 0.2$ to $1.6 \pm 0.2$ and sample A6 HELLO (Carrot and Apple) $10 \pm 0.2$ to $4.5 \pm 0.2$, while the samples A3 HiPP (Apple and banana) value of Vitamin $\mathrm{C}$ is lower $8.9 \pm 0.2$ to $7.2 \pm 0.2$ and lower in the sample A5 FRUTEK (Banana) $8.7 \pm 0.2$ to $6.3 \pm 0.2$. Statistically, storage interval and treatments had significantly $(p<0.05)$ effect on the Vitamin $C$ value of all samples during storage.

It is known that losses of vitamin $\mathrm{C}$ occur during processing and storage. That these losses may be used as an indicator of the aggression to nutritional value suffered in the industrial or culinary process (Mesías-García, Guerra-Hernández and García-Villanova, 2010). It is thought that vitamin $\mathrm{C}$ undergoes oxidation and substantial losses during processing, storage, and heat treatment of fruit and vegetables during the processing periods (El-Ishaq and Obirinakem, 2015). To prevent such losses, vitamin $\mathrm{C}$ may be added to vegetable and fruitbased baby foods, and optimization of the $\mathrm{pH}$ value. If the $\mathrm{pH}$ value increases from 3 to 6 , vitamin $\mathrm{C}$ oxidation increases (Fan, 2005). Uğur et al. (2020) reported that the determined concentrations ranged from 0.1 to $8.5 \mathrm{mg} \cdot 100 \mathrm{~g}^{-1}$ in samples that were not-fortified with vitamin C. Also, the concentration of vitamin $\mathrm{C}$ was very low in samples that were not containing added vitamin $C$ compared to other fruit and vegetable-based baby foodstuffs. Silva et al. (2018) found that vitamin C concentration in baby foods ranged from 1.50 to $144 \mathrm{mg} .100 \mathrm{~g}^{-1}$ and the measured amount of vitamin $\mathrm{C}$ was $50 \%$ higher than the reported concentration on the label. In the same study, all values were within the allowed limits in compliance with EU legislation. Brandon et al. (2014) revealed that determining vitamin $\mathrm{C}$ concentrations ranged from 97 to $147 \%$ of the declared concentration in infant formula. In the study conducted by Mesías-García, Guerra-Hernández and García-Villanova (2010) for vegetable-based baby foods, no vitamin $\mathrm{C}$ was found in any of the products and it was thought that naturally found vitamin C was completely lost during processing. Carbonell-Capella et al. (2014) revealed that vitamin C contents were between 1.9 and $71.5 \mathrm{mg} .100 \mathrm{~g}^{-1}$ in 23 fruitbased baby foods and the lowest vitamin $\mathrm{C}$ amounts $\left(0-2.4 \mathrm{mg} \cdot 100 \mathrm{~g}^{-1}\right)$ were determined in fruit-based baby foodstuffs which were not-fortified with vitamin C. When the declared amount was subtracted from the analyzed amount, very small amounts of vitamin $\mathrm{C}$ were found in the samples. It is thought that vitamin $\mathrm{C}$ undergoes substantial losses in the processing periods. Our findings are congruent with the measured amount of vitamin $\mathrm{C}$ was generally the reported amount in vitamin $\mathrm{C}$ added and declared commercial fruits baby food. Our findings are congruent with the above-mentioned studies that the measured amount of vitamin $\mathrm{C}$ decreased during storage time and heat treatment.
Also, commercial fruits based baby food as a good source of sugars, and consequently, they are a good source of energy. A decrease was observed in the total number of sugars on these samples during storage (Table 2). The average value varied from $11.1 \pm 0.1$ to $9.0 \pm 0.1$ sample A4 HiPP (Pear), $12.4 \pm 0.1$ to $10.2 \pm 0.1$ sample A1 HiPP (Apple and Berry fruits), $13.2 \pm 0.1$ to $11.1 \pm 0.1$ sample A3 HiPP (apple and banana), $15.8 \pm 0.1$ to $13.1 \pm 0.1$ sample A5 FRUTEK (Banana), $16.0 \pm 0.1$ to $13.9 \pm 0.1$ sample A2 HiPP (plum) as well as higher in the sample A6 HELLO (carrot and apple) $18.9 \pm 0.1$ to $18.3 \pm 0.1$. During storage in different temperatures, sucrose in fruits is continuously converted into fructose and glucose which results in a reduction in the total number of sugars. Results demonstrated that storage and temperature treatment have a significant $(p<0.05)$ effect on samples of baby food.

An increase was observed in reducing sugars during storage and temperature treatment (Table 2). The average value varied from $9.1 \pm 0.1$ to $11.3 \pm 0.1$ sample A4 HiPP (Pear), $9.2 \pm 0.1$ to $11.3 \pm 0.1$ sample A1 HiPP (Apple and Berry fruits), $12.1 \pm 0.1$ to $14.3 \pm 0.1$ sample A3 HiPP (Apple and banana), $9.9 \pm 0.1$ to $11.9 \pm 0.1$ sample A5 FRUTEK (Banana), $11.2 \pm 0.1$ to $13.4 \pm 0.1$ sample A2 HiPP (Plum) as well as higher in the sample A6 HELLO (Carrot and apple) $15.0 \pm 0.1$ to $17.2 \pm 0.1$. A raise in reducing sugars is due to the inversion of sucrose to reducing sugar because of acids. A conversation of pectin into fructose and glucose because of the rise in temperature during storage was observed. Storage and temperature treatment results were significant $(p<0.05)$.

Many products that are frequently marketed to and consumed by infants and young children contain sugars that are far more than what is considered nutritionally beneficial and/or different from that stated on the nutrition label (Walker and Goran, 2015). Total sugar content is positively correlated with fruit and vegetable content in commercial baby foods, particularly in spoonable foods (6.8 g sugar per $100 \mathrm{~g}$ ), suggesting that they may be used as sweetening agents (Garcia, McLean and Wright, 2016).

Our results were in concordance to those found by Batkan, Kundakçi and Ergönül (2012) reported that the average of total sugars was $9.94-10.97 \mathrm{~g}^{1} 100 \mathrm{~g}^{-1}$ and that the average of reducing sugars was $8.39-10.08$ g. $100 \mathrm{~g}^{-1}$. It was found that the storage period significantly affected the total sugar and reducing sugar contents of all samples $(p<0.05)$. In the period of storage, total sugar and reducing sugar contents of all samples showed an increasing trend. It is thought that this increase is related to the degradation of starch to glucose and maltose.

The values of proteins to samples of commercial fruits based baby food are lower. Fruits baby food do not count as protein foods and varied between $0.5 \pm 0.1$ to sample A6 HiPP (Pear), $0.5 \pm 0.1$ to sample A3 HiPP (Apple and Berry fruits), $0.5 \pm 0.1$ to sample A5 HiPP (Apple and banana), $0.5 \pm 0.1 \mathrm{~g} .100 \mathrm{~g}^{-1}$ to sample A4 HiPP (Plum) and the lowest of samples A8 HELLO (Carrot and apple) $0.1 \pm 0.1$ while the highest $0.8 \pm 0.1$ to sample A7 FRUTEK (Banana). No change in protein values was observed during storage and temperature treatment and statistically is significantly $(p<0.05)$. 
Also, commercial fruits based on baby food are not fatrich foods. The content of lipids is low and varies from $0.04 \pm 0.01$ to sample A7 FRUTEK (Banana), while in other samples its value is $0.1 \pm 0.01$ to samples A3 HiPP (Apple and Berry fruits), A4 HiPP (Plum), A5 HiPP (Apple and banana), A8 HELLO (Carrot and apple)), while the highest value is in the sample A6 HiPP (Pear) $0.3 \pm 0.01$. Also, no change in lipids values was observed during storage and temperature treatment and statistically is significantly $(p<0.05)$.

It is very difficult to compare data with other authors because there is limited data in the literature about proteins and lipids to samples of commercial fruits-based baby food. Our results were the first in this study.

The obtained results can be useful in clarifying the changes in the quality of commercial fruits based baby food during storage in different temperature treatments $\left(4^{\circ} \mathrm{C}, 20^{\circ} \mathrm{C}, 40^{\circ} \mathrm{C}, 60^{\circ} \mathrm{C}\right)$.

\section{CONCLUSION}

The samples of commercial baby food based fruits stored at refrigeration condition $\left(4{ }^{\circ} \mathrm{C}\right)$ and room temperature $\left(20^{\circ} \mathrm{C}\right)$ had the maximum quality and maximum nutrients stability as compared to the treatment of increased temperature $\left(40{ }^{\circ} \mathrm{C}\right.$ and $\left.60{ }^{\circ} \mathrm{C}\right)$ during 15 days of storage.

Samples of commercial fruits based baby food with trade name: HiPP (Apple and Berry fruits), HiPP (Plum), HiPP (Apple and Banana), HiPP (Pear), FRUTEK (Banana), and HELLO (Carrot and Apple) were purchased from the market and pharmacies in Kosovo during the period June 2019. However, as a precaution, storage remarks in the product labels should always be followed. All samples of baby food are produced by foreign companies since currently, no Kosovo manufacturers are producing this range of products.

This is the first research of this type in Kosovo and it should give us a novel result. Nutrition education of mothers and health workers in kindergarten on the selection and preparation of the right type of baby foods and weaning practices will go a long way in improving the nutritional status of infants and children in the country.

\section{REFERENCES}

Al-Othman, A. M., Khan, M. A., Al-Kanhal, M. A. 1997. Nutritional evaluation of some commercial baby foods consumed in Saudi Arabia. International Journal of Food Sciences and Nutrition, vol. 48, no. 4, p. 229-236. https://doi.org/10.3109/09637489709028566

AOAC. 2005. Official Methods of Analysis: Official Method for Fat Extraction. Method No. 920.85. Association of Official Analytical Chemists, Washington, DC.

AOAC. 2016. Official method of analysis. Maryland, USA : ublication by AOAC International.

Azemi, D., Koraqi, H., Selimi, S., Durmishi, N., Lajqi, V. 2019. Nutritional quality of commercial baby food based on cereals. In UBT International Conference, Pristina, Kosovo, 7 p. ISBN 978-9951-550-19-2. Available at: https://knowledgecenter.ubt-

uni.net/conference/2019/events/429

Batkan, A., Kundakçi, A., Ergönül, B. 2012. Effect of holding period prior to storage on the chemical attributes of Starking Delicious apples during refrigerated storage. Ciência e Tecnologia de Alimentos, vol. 32, no. 2, p. 223-227. https://doi.org/10.1590/S0101-20612012005000041
Brandon, E. F. A., Bakker, M. I., Kramer, E., Bouwmeester, H., Zuidema, T., Alewijn, M. 2014. Bioaccessibility of vitamin $\mathrm{A}$, vitamin $\mathrm{C}$ and folic acid from dietary supplements, fortified food and infant formula. International Journal of Food Sciences and Nutrition, vol. 65, no. 4, p. 426-435. https://doi.org/10.3109/09637486.2013.869795

Calabretti, A., Calabrese, M., Campisi, B., Bogoni, P. 2017. Quality and Safety in Commercial Baby Foods. Journal of Food and Nutrition Research, vol. 5, no. 8, p. 587-593. https://doi.org/10.12691/jfnr-5-8-9

Carbonell-Capella, J. M., Barba, F. J., Esteve, M. J., Frígola, A. 2014. Quality parameters, bioactive compounds and their correlation with antioxidant capacity of commercial fruit-based baby foods. Food Science and Technology International, vol. 20, no. 7, p. 479-487. https://doi.org/10.1177/1082013213492523

Čížková, H., Ševčík, R., Rajchl, A., Voldřich, M. 2009. Nutritional Quality of Commercial Fruit Baby Food. Czech Journal of Food Sciences, vol. 27, p. S134-S137. https://doi.org/10.17221/616-CJFS

Codex Alimentarius. 1991. International Food Standards. Guidelines on formulated complementary foods for older infants and young children CAC/GL- 8-1991. Adopted in 1991. Amended in 2017. Revised in 2013.

El-Ishaq, A., Obirinakem, S. 2015. Effect of temperature and storage on vitamin $\mathrm{C}$ content in fruits juice. International Journal of Chemical and Biomolecular Science, vol. 1, no. 2, p. 17-21.

Fan, X. 2005. Formation of furan from carbohydrates and ascorbic acid following exposure to ionizing radiation and thermal processing. Journal of Agricultural and Food Chemistry, vol. 53, no. 20, p. 7826-7831. https://doi.org/10.1021/jf051135x

Fügel, R., Carle, R., Schieber, A. 2005. Quality and authenticity control of fruit purees, fruit preparations and jams-a review. Trends in Food Science \& Technology, vol. 16, no. 10, p. 433-441. https://doi.org/10.1016/j.tifs.2005.07.001

Garcia, L. A., McLean, K., Wright, M. C. 2016. Types of fruits and vegetables used in commercial baby foods and their contribution to sugar content. Maternal and Child Nutrition, vol. 12, no. 4, p. 838-847. https://doi.org/10.1111/mcn.12208

García, L. A., Raza, S., Parrett, A., Wright, M. C. 2015. Nutritional content of infant commercial weaning foods in the UK. Archives of Disease in Childhood, vol. 98, no. 10, p. 793-797. https://doi.org/10.1136/archdischild-2012-303386

Garcia, L. A., Vargas, E., Lam, P. S., Shennan, D. B., Smith, F., Parrett, A. 2014. Evaluation of a cooking skills programme in parents of young children - a longitudinal study. Public Health Nutrition, vol. 17, no. 5, p. 1013-1021. https://doi.org/10.1017/S1368980013000165

Jackson, A. A. 2015. Feeding the normal infant, child and adolescent. Medicine, vol. 43, no. 2, p. 127-131. https://doi.org/10.1016/j.mpmed.2014.11.005

Jie, L., Xiao-ding, L., Yun, Z., Zheng-dong, Z., Zhi-ya, Q., Meng, L., Shao-hua, Z., Shuo, L., Meng, W., Lu, Q. 2013. Identification and thermal stability of purple-fleshed sweet potato anthocyanins in aqueous solutions with various $\mathrm{pH}$ values and fruit juices. Food Chemistry, vol. 136, no. 3-4, p. 1429-1434. https://doi.org/10.1016/j.foodchem.2012.09.054

Kohlboeck, G., Sausenthaler, S., Standl, M., Koletzko, S., Bauer, C. P., von Berg, A., Berdel, D., Krämer, U., Schaaf, B., Lehmann, I., Herbarth, O., Heinrich, J. 2012. Food intake, diet quality and behavioral problems in children: Results from the GINI-plus/LISA-plus Studies. Annals of Nutrition and 
Metabolism, vol. 60, no. 4, p. 247-256. https://doi.org/10.1159/000337552

Mesías-García, M., Guerra-Hernández, E., GarcíaVillanova, B. 2010. Determination of furan precursors and some thermal damage markers in baby foods: ascorbic acid, dehydroascorbic acid, hydroxymethylfurfural and furfural. Journal of Agricultural and Food Chemistry, vol. 58, no. 10, p. 6027-6032. https://doi.org/10.1021/jf100649z

Nielsen, S. S. 2009. Phenol-Sulfuric Acid method for Total Carbohydrates. In Nielsen, S. S. Food Analysis Laboratory Manual. Boston, USA, : Springer-Verlag, p. 47-53. ISBN 978-1-4419-1463-7. $\quad$ https://doi.org/10.1007/978-1-4419$\underline{1463-7 \quad 6}$

Prchāová, J., Čížková, H., Ševčík, R., Hanušová, K., Rajchl, A. 2016. Evaluation of shelf-life of fruit baby food. Agronomy Research, vol. 14, no. 2, p. 556-568. Available at: https://agronomy.emu.ee/category/volume-14/number-2-

volume-14/

Seidel, K., Kahl, J., Paoletti, F., Birlouez, I., Busscher, N., Kretzschmar, U., Särkkä-Tirkkonen, M., Seljåsen, R., Sinesio, F., Torp, T., Baiamonte, I. 2015. Quality assessment of baby food made of different pre-processed organic raw materials under industrial processing conditions. Journal of Food Science and Technology, vol. 52, no. 2, p. 803-812. https://doi.org/10.1007/s13197-013-1109-5

Silva, M. A., Gonçalves Albuquerque, T., Beatriz P. P. Oliveira, M., Costa, H. S. 2018. Vitamin C evaluation in foods for infants and young children by a rapid and accurate analytical method. Food Chemistry, vol. 267, p. 83-90. https://doi.org/10.1016/j.foodchem.2017.11.046

Touati, N., Barba, J. F., Louaileche, H., Frigola, A., Esteve, J. M. 2016. Effect of storage time and temperature on the quality of fruit nectars: Determination of nutritional loss indicators. Journal of Food Quality, vol. 39, no. 3, p. 209217. https://doi.org/10.1111/jfq.12189

Uğur, H., Çatak, J., Mızrak, Ö. F., Çebi, N., Yaman, M. 2020. Determination and evaluation of in vitro bioaccessibility of added vitamin $\mathrm{C}$ in commercially available fruit-, vegetable-, and cerealbased baby foods. Food

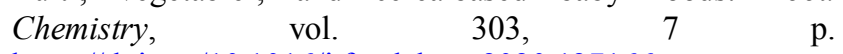
https://doi.org/10.1016/j.foodchem.2020.127166

Usal, M., Sahan, Y. 2020. In vitro evaluation of the bioaccessibility of antioxidative properties in commercially baby foods. Journal of Food Science and Technology, vol. 57, no. 9, p. 3493-3501. https://doi.org/10.1007/s13197-020$\underline{04384-8}$
Walker, W. R., Goran, I. M. 2015. Laboratory Determined Sugar Content and Composition of Commercial Infant Formulas, Baby Foods and Common Grocery Items Targeted to Children. Nutrients, vol. 7, no. 7, p. 5850-5867. https://doi.org/10.3390/nu7075254

Zein, H., ElSayed Bhnsawy, M. R., Arafa, A. S. 2019. Nutritional Evaluation of Some Prepared Baby's Complementary Food Mixtures for Weaning Period. World Journal of Dairy \& Food Sciences, vol. 14, no. 1, p. 79-86. Available at: https://idosi.org/wjdfs/wjdfs14(1)19/10.pdf

Zulueta, A., Esteve, M. J., Frasquet, I., Frígola, A. 2007. Vitamin C, vitamin A,phenolic compounds and total antioxidant capacity of new fruit juice and skim milk mixture beverages marketed in Spain. Food Chemistry, vol. 103, no. 4 , https://doi.org/10.1016/j.foodchem.2006.10.052

$1365-1374$.

\section{Contact address:}

*Hyrije Koraqi PhD, UBT College-Higher Education Institution, Faculty of Food Science and Biotechnology, Str. Kalabria, nn., 10000, Prishtina, Kosovo, Tel.: +38344411553 ,

E-mail: hyrie.koraqi@ubt-uni.net

ORCID: https://orcid.org/0000-0001-8159-301X

Namik Durmishi PhD, University of Tetova, Faculty of Food Technology and Nutrition, Str. Ilinden, nn. 1200 Tetova, Republic of North Macedonia. Tel.: +0038971366142 ,

E-mail: namik.durmishi@,unite.edu.mk

ORCID: https://orcid.org/0000-0002-9159-4806

Diellëza Azemi Msc., UBT College-Higher Education Institution, Faculty of Food Science and Biotechnology, Str. Kalabria, nn., 10000, Prishtina, Kosovo, Tel.:+38344456677,

E-mail: da38993@ubt-uni.net

ORCID: https://orcid.org/0000-0001-6837-6723

Sara Selimi Msc., UBT College-Higher Education Institution, Faculty of Food Science and Biotechnology, Str. Kalabria, nn., 10000, Prishtina, Kosovo, Tel.:+38345566678,

E-mail: ss40105@ubt-uni.net

ORCID: https://orcid.org/0000-0001-7223-922X

Corresponding author: * 